\title{
VISUALISASI HASIL MESIN UJI TARIK GOTECH GT-7010-D2E DALAM BENTUK GRAFIK SECARA REAL TIME
}

\author{
Anggoro Suryo Pramudyo1, Andi Rachmansyah², Suhendar ${ }^{3}$ \\ Jurusan Teknik Elektro Universitas Sultan Ageng Tirtayasa \\ Jl. Jenderal Sudirman km.3 Cilegon-Banten-Indonesia 42435 \\ 12pramudyo3@yahoo.com; ${ }^{2}$ andirachmansyahft@gmail.com; ${ }^{3}$ suhendar@ft-untirta.ac.id
}

\begin{abstract}
ABSTRAK - GOTECH GT-7010-D2E adalah mesin uji tarik yang digunakan di Laboratorium Teknik Metalurgi UNTIRTA. Mesin tersebut digunakan baik untuk praktikum Material Teknik maupun pengujian spesimen yang diminta oleh beberapa industri. Mesin tersebut dapat melakukan pengujian tarik dengan baik, namun untuk analisanya dilakukan secara manual, sehingga membutuhkan waktu yang banyak dan keakuratan hasil analisanya tidak terlalu akurat. Oleh karena itu, dibutuhkan sebuah perangkat lunak yang dapat menganalisa hasil uji tarik dalam bentuk grafik secara real time. Perangkat lunak visualisasi dibuat menggunakan Visual Basic 6.0 dan data hasil mesin uji tarik disimpan menggunakan basis data Microsoft Access. Perangkat lunak tersebut dibuat untuk merekam setiap karakter yang tampil di LCD pada control panel mesin uji tarik lalu kemudian mengolahnya untuk dijadikan grafik. Berdasarkan hasil implementasi spesimen plat dan kawat membuktikan bahwa perbedaan nilai pengamatan antara penggunaan perangkat lunak visualisasi lebih akurat dan efektif dalam waktu penggunaannya, jika dibandingkan dengan pengamatan manual yang membutuhkan analisa lebih lanjut dari hasil pengujian. Dalam perangkat lunak visualisasi hasil uji tarik, sifat-sifat mekanis dapat dianalisa secara langsung dari hasil pengujian data serta grafik yang diperoleh secara real time.
\end{abstract}

Kata Kunci : GOTECH GT-7010-D2E, visualisasi, mesin uji tarik

\begin{abstract}
Gotech GT-7010-D2E is a tensile testing machine used in Metallurgical Engineering Laboratory UNTIRTA. The machine are used both for practical and Materials Engineering specimen testing demanded by several industries. The machine can perform tensile tests well, but for the analysis is done manually, so it requires a lot of time and accuracy of the analysis results are not very accurate. Therefore, it's needed a software that can analyze the results of the tensile test in the form of graphs in real time. Software visualization is created using Visual Basic 6.0 and data from tensile testing machine is stored using Microsoft Access database. The software is designed to record any characters that appear in the LCD on the control panel of a tensile testing machine and then process them to be a graphic. Based on the results of the implementation of the specimen plate and wire observations prove that the difference between the use of visualization software is more accurate and effective in their use of time, compared to manual observation that requires further analysis of the test results. In software visualization results of tensile test, the mechanical properties can be analyzed directly from the test results and graphs of data obtained in real time.
\end{abstract}

Key Words : GOTECH GT-7010-D2E, visualization, tensile testing machine

\section{PENDAHULUAN}

Uji tarik merupakan salah satu pengujian mekanik material dasar yang digunakan dalam bidang konstruksi di dunia pendidikan saat ini, contohnya pada praktikum material uji tarik Laboratorium Manufaktur Metalurgi
Universitas Sultan Ageng Tirtayasa (UNTIRTA). Pentingnya pengujian praktikum dimaksudkan untuk mengetahui informasi data yang akurat tentang rancangan dasar kekuatan bahan serta pengamatan sifat mekanik material uji yang tergambar langsung melalui kurva hubungan antara tegangan dan regangan selama proses pengujian [1]. Dengan adanya kurva 
tegangan regangan saat pengujian dilakukan, maka sifat mekanik suatu spesimen dapat diketahui. Namun kenyataannya, saat pengujian dilakukan menggunakan mesin uji tarik GOTECH GT-7010-D2E milik Laboratorium Metalurgi UNTIRTA, masih memiliki beberapa keterbatasan dari segi perolehan hasil data parameter maupun perolehan secara langsung kurva grafik tersebut. Selain itu belum mampunya mesin dalam hal merekam setiap data hasil uji tarik ke dalam basis data seperti instrumen pengujian tarik lainnya menjadi salah satu kendala saat pengujian tarik ini dilakukan.

Pembelian alat data recording dan pengembangan alat yang cukup mahal menjadi satu hambatan untuk melengkapi kekurangan dari alat tersebut sebagai penunjang selama praktikum. Oleh sebab itu, mesin uji tarik yang telah ada saat ini butuh penyempurnaan beberapa fasilitas lebih lanjut baik secara sistem penyimpanan data pengujian dalam bentuk basis data, maupun perolehan data yang telah diolah melalui tampilan grafik real time ke dalam PC melalui tampilan perangkat lunak. Adanya perancangan visualisasi hasil mesin uji tarik GOTECH GT-7010-D2E dengan PC, diharapkan dapat mempermudah pengguna dalam menganalisa sifat-sifat mekanis dari hasil pengujian.

\section{TINJAUAN PUSTAKA}

\section{A. GOTECH GT-7010-D2E}

GOTECH GT-7010-D2E merupakan salah satu jenis mesin uji tarik. Mesin tersebut memiliki kapasitas maksimum sebesar $5 \mathrm{kN}$ dan memiliki bagian-bagian seperti pada gambar 1 :

1. Sensor Load cell berfungsi untuk mengukur besarnya gaya tarik.

2. Upper grip adalah cengkraman statis pegangan spesimen uji bagian atas.

3. Control panel adalah panel bagian kendali motor bagian lower grip, terdapat display untuk menginput data dan menampilkan hasil output data.

4. Lower grip adalah cengkraman dinamis pegangan spesimen uji bagian bawah.

5. Gearbox motor berfungsi sebagai penggerak lower grip saat eksekusi pengujian berlangsung, sekaligus merupakan sumber data pertambahan panjang.

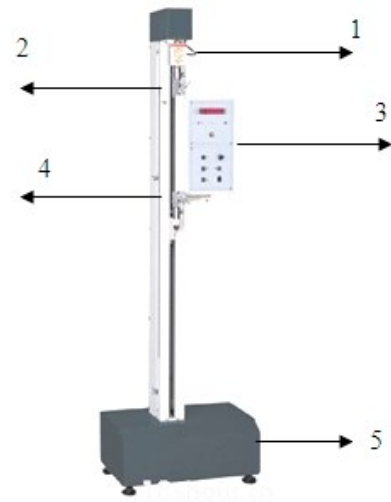

Gambar 1. GOTECH GT-7010-D2E

\section{B. Visualisasi}

Visualisasi adalah konversi data dalam format visual, tabel maupun grafik sehingga karakteristik dari data dan relasi di antara item data atau komponen yang terkait dapat dianalisis dan dilaporkan.

\section{Uji Tarik}

Uji tarik adalah suatu metode yang digunakan untuk menguji kekuatan tarik, kekerasan, keuletan dan ketangguhan suatu bahan/material dengan cara memberikan beban gaya yang berlawanan arah dalam satu garis lurus [2]. Pengujian uji tarik memainkan peranan penting dalam mengevaluasi sifat-sifat dasar bahan material yang bertujuan untuk mengukur kekuatan suatu material terhadap gaya tarik yang diberikan secara lambat (tensile testing machine). Dalam pengujiannya, spesimen uji yang telah terstandarisasi ditarik dengan gaya atau tegangan tarik yang diberikan secara perlahan dengan proses pembebanan berporos tunggal (uniaxial), sehingga spesimen uji mengalami peregangan, bertambah panjang dan hingga akhirnya timbul perpatahan.

Gaya (F) yang diberikan mesin uji tarik pada spesimen uji, merupakan hasil dari sensor load cell yang ditransmisikan pada grip bagian atas mesin uji tarik, dengan maksud untuk mengetahui serta mendeteksi beban yang mampu diberikan suatu material pengujian. Sedangkan pertambahan panjang $\left(\mathrm{L}-\mathrm{L}_{\mathrm{o}}\right)$ didapat dari hasil integrasi pergerakan servo mesin uji tarik yang ditransmisikan menjadi besaran nilai jarak pada pergerakan grip bagian bawah. 


\section{Kurva Tegangan dan Regangan}

Persamaan penyusun representasi kurva tegangan-regangan berdasarkan parameterparameter berikut :

$$
\begin{aligned}
& \sigma=\frac{F}{A_{0}} \\
& e=\frac{L-L_{0}}{L_{0}}
\end{aligned}
$$

Keterangan:

$$
\begin{array}{ll}
\sigma & =\text { Stress atau tegangan }\left(\mathrm{N} / \mathrm{mm}^{2}\right) \\
\mathrm{F} & =\text { Beban }(\mathrm{N}) \\
\mathrm{Ao} & =\text { Luas Penampang }\left(\mathrm{mm}^{2}\right) \\
\mathrm{e} & =\text { Strain atau regangan } \\
\mathrm{L} & =\text { Panjang Akhir }(\mathrm{mm}) \\
\mathrm{Lo} & =\text { Panjang Mula-mula }(\mathrm{mm})
\end{array}
$$

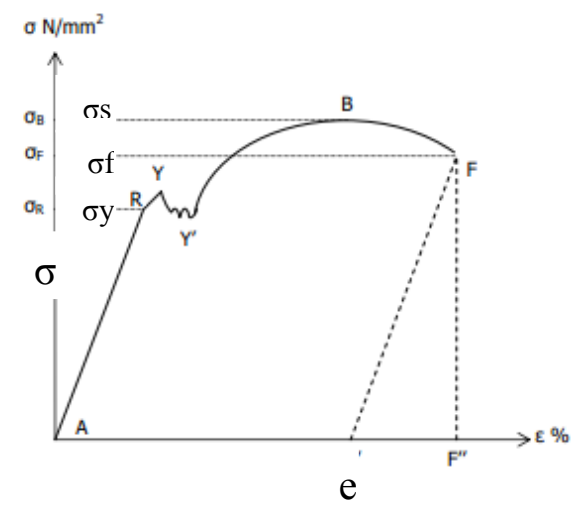

Gambar 2. Profil Data Hasil Uji Tarik

\section{E. Liquid Crystal Display}

LCD (Liquid Crystal Display) adalah suatu display yang digunakan untuk menampilkan data/karakter dalam bentuk matrik dan struktur perintahnya yang telah diseting dari pabrik. LCD dalam penelitian ini terdapat pada bagian control panel mesin uji tarik yang digunakan untuk menampilkan informasi data dalam bentuk karakter selama proses uji tarik berlangsung. Umumnya LCD tersusun atas dua bagian penting, yaitu :

1. Gelas LCD yang berisi crystal cair

2. Kontroller HD44780, terdapat fungsi penerima KARAKTER dan INSTRUKSI.
Fungsi Pin Control LCD adalah sebagai berikut:

1. Pin RS (Register Select)

RS adalah pin yang berfungsi sebagai selektor register.

2. Pin R/W (Read/Write)

$\mathrm{R} / \mathrm{W}$ adalah pin yang berfungsi untuk menentukan mode baca atau mode tulis dari data yang terdapat pada DB0-DB7.

3. Pin $\mathrm{E}$

Enable (E), berfungsi sebagai Enable Clock LCD, dengan logika 1 setiap kali pengiriman atau pembacaan data. Jika menggunakan 8-bit (DB0 - DB7) maka hanya 1 siklus enable, untuk mode 4-bit (DB4 - DB7) maka membutuhkan 2 siklus enable.

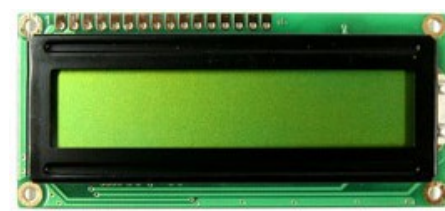

Gambar 3. Bentuk Fisik LCD 2x16

\section{F. Mikrokontroler AVR}

Mikrokontroler adalah sebuah sistem komputer fungsional dalam sebuah chip. Dalam penelitian ini hanya mengkhususkan menggunakan AVR seri ATMega 8 dengan alasan kemampuan yang dibutuhkan terpenuhi dan dari segi ekonomis relatif murah.

\section{G. Penelitian Sebelumnya}

Pada penelitian sebelumnya tentang Perencanaan dan Pembuatan Alat Uji Tarik Untuk Menunjang Praktikum Uji Tarik Pada Lab. Logam Universitas Muhammadiyah Malang Berbasis PC [3]. Penelitian ini membahas rencana tentang rancangan alat uji tarik yang sudah ada, dengan mengembangkan plotter mekanisnya sebagai alat bantu rekam selama proses uji tarik berlangsung. Konsep penelitian ini bekerja dengan mengambil output dari mesin uji tarik yang menuju ke plotter mekanis yang merupakan tegangan analog, sedangkan perangkat lunak yang digunakan adalah Visual Basic. 
Penelitian kedua adalah tentang Perancangan dan Pembuatan Interface Alat Uji Tarik Serat Berbasis PC dan Mikrokontroler [4]. Penelitian ini membahas tentang sistem interface yang menghubungkan alat uji tarik serat dengan PC. Variabel yang diukur adalah daya listrik pada solenoid, daya listrik didapatkan setelah mengetahui besarnya arus dan hambatan pada solenoid.

Penelitian ketiga adalah tentang Pembuatan Alat Uji Tarik Material adalah merancang sebuah instrument uji tarik yang mampu mengetahui karakteristik dari sifat mekanik suatu bahan material logam menggunakan beberapa perancangan dari segi perangkat keras dan perangkat lunak [5]. Manfaat dari penelitian tersebut adalah sebagai parameter prinsip dasar kerja mesin uji tarik untuk mengetahui bagaimana langkah agar dapat meng-interface-kan alat dengan PC.

\section{METODOLOGI ATAU TEORI}

\section{A. Metodologi Penilitian}

Pada penelitian ini dirancang sebuah perangkat keras berbasis mikrokontroler yang digunakan sebagai kit capture, agar mesin uji tarik GOTECH GT-7010-D2E terkonensi dengan PC, dengan tujuan setiap hasil pengujian mampu ditampilkan di PC. Serta merancang perangkat lunak yang kemudian dibangun menggunakan Visual Basic 6.0 dan Microsoft Access 2007, sebagai fasilitas mesin uji tarik yang dapat menampilkan hasil data pengujian dalam bentuk visual kurva uji tarik tegangan-regangan.

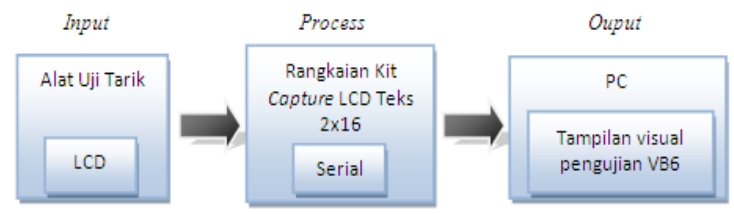

Gambar 4. Diagram Blok Sistem Rancangan
Prinsip dasar kit capture bekerja berdasarkan prinsip dasar dari LCD, prinsipnya terbagi menjadi 2: sistem utama dan sistem saat pembacaan data. Sistem utama berfungsi sebagai pegecek data dalam buffer dan pengiriman data dalam buffer ke PC. Buffer FIFO adalah tempat hasil bit capture disimpan. Proses pembacaan bit data pin D0-D7 LCD pada kit ini akan dilakukan ketika program utama di-interrupt (disela), yaitu saat pin $\mathrm{E}$ menerima logika 0. Dalam hal ini, kondisi pin $\mathrm{R} / \mathrm{W}$ berlogika 0 , dan pin RS berlogika 1 . Bit data yang dibaca berjumlah 8 bit untuk satu karakter. Sedangkan ketika pin RS berlogika 0 maka data itu merupakan instruksi yang telah diubah menjadi karakter ENTER ('In') yaitu pembeda antara data karakter yang dibaca dari baris pertama dan baris kedua. Pembacaan untuk 1 karakter dilakukan dengan mode 4 bit (disesuaikan dengan mode yang dipakai pada LCD mesin uji tarik), yaitu membaca 2 nibble data yang dikirim untuk membuat sepenuhnya menjadi 8 bit, artinya pertama dibaca untuk 4 bit MSB (Most Significant Bit) lalu selanjutnya dibaca 4 bit LSB (Least Significant Bit) dengan pulsa clock E setiap nibble-nya. Setelah data lengkap menjadi 8 bit, selanjutnya disimpan pada buffer FIFO.

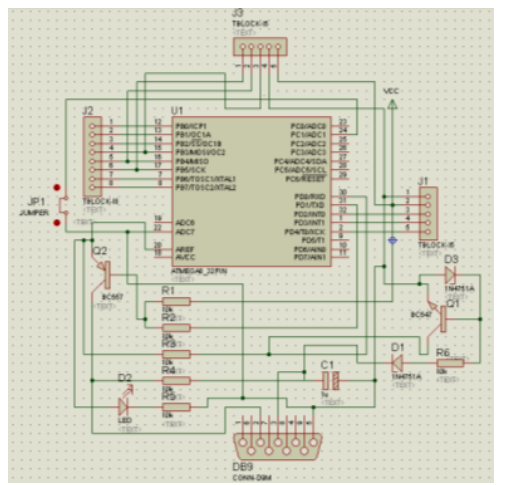

Gambar 5. Sistem Minimum Mikrokontroler ATMega 8 (kit capture)

\section{Perangkat Keras}



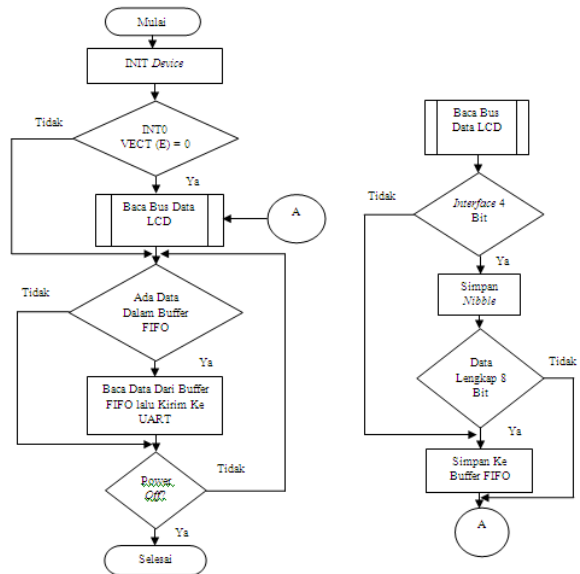

Gambar 6. (a) Flowchart Kirim serial UART (b) Flowchart Interupsi vector 0

\section{Perangkat Lunak}

Parameter-parameter yang berhubungan dengan pengujian untuk memperoleh kurva uji tarik dari proses capture yang didapatkan adalah parameter Length, Area, Force dan Delta $X$. Perangkat lunak ini bertugas untuk menerima sejumlah data karakter yang dikirim dari hasil pembacaan data kit LCD mesin uji tarik, selanjutnya data diolah atau di-parsing dengan inisial-inisial yang identik saat capture data berada pada kondisi tampilan nilai-nilai parameter yang akan diambil nilainya.

Alur Parsing dari kit capture LCD ke PC:

a. Alur parsing dimulai berdasarkan data hasil capture yang diterima oleh perangkat lunak visual dengan membuka jalur port yang digunakan sebagai inputan kit.

b. Kemudian dari data hasil capture yang diterima, digunakan inisial-inisial identik saat kondisi dari parameter-parameter menampilkan nilai yang akan diambil nilainya.

c. Setelah inisial dikenali dari setiap parameter, maka selanjutnya adalah mengolah data-data inisial.

d. Apabila data inisial telah selesai diolah dan didapat data Length, Area, Force, Delta X, Force Max, Delta X (Force max), maka tahap selanjutnya adalah menampilkan data-data parameter tersebut pada masingmasing textbox serta menampilkan hasil perhitungan dari parameter ke dalam bentuk representasi grafik tegangan-regangan. e. Setelah data-data tersebut ditampilkan dan proses pengujian selesai, maka selanjutnya menutup port serial.

\section{HASIL DAN PEMBAHASAN}

\section{A. Hasil}

Sistem visualisasi mesin uji tarik GOTECH GT-7010-D2E dengan PC yang telah dirancang pada penelitian ini terbagi menjadi dua bagian utama, yaitu perangkat keras dan perangkat lunak.

\section{Perangkat Keras}

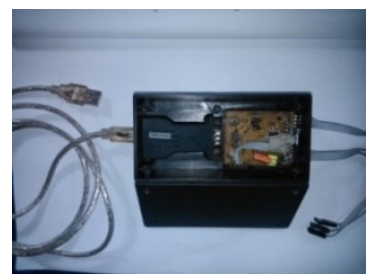

Gambar 7. Kit Capture sebagai Koneksi Mesin Uji Tarik GOTECH GT-7010-D2E dengan PC

\section{a. Pengujian Sistem Minimum Mikrokontroler ATMega 8}

Tabel 1. Uji Tegangan Pada Sistem Minimum

\begin{tabular}{ccc}
\hline $\begin{array}{c}\text { Pengukuran } \\
\text { ke }\end{array}$ & $\begin{array}{c}\text { Tegangan } \\
\text { LCD } \\
\text { Mesin Uji } \\
\text { Tarik } \\
\text { (Volt) }\end{array}$ & $\begin{array}{c}\text { Pengukuran } \\
\text { Tegangan } \\
\text { mikrokontroler } \\
\text { (kit Capture } \\
\text { LCD teks) } \\
\text { (Volt) }\end{array}$ \\
\hline 1 & 5.02 & 5.01 \\
2 & 5.02 & 5.01 \\
3 & 5.02 & 5.01 \\
4 & 5.02 & 5.01 \\
5 & 5.02 & 5.01 \\
\hline Rata-rata & 5.02 & 5.01 \\
\hline
\end{tabular}

Dalam hal ini tegangan yang di-supply untuk kit dalam pengujian tegangan rata-rata 5 Volt. Pada rangkaian ini, kestabilan tegangan sudah baik.

\section{Perangkat Lunak}


Realisasi pemrograman utama perangkat lunak visual uji

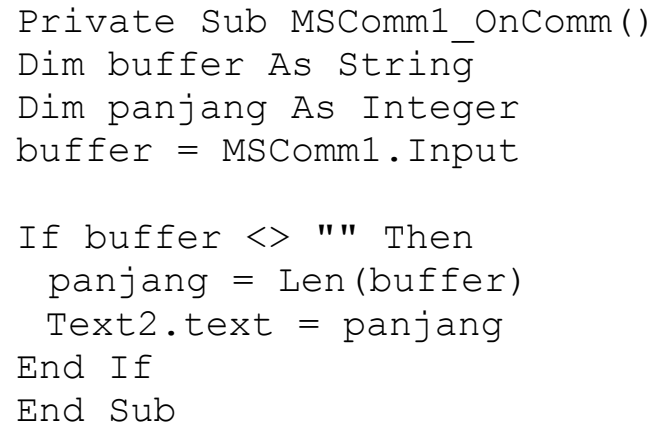

Variabel buffer dengan tipe data string adalah merupakan bentukan angka dan huruf, buffer merupakan variabel yang bertugas sebagai penerima data dari port serial atau MSComm1.Input. Sementara variabel panjang bertipe Integer, dengan maksud untuk menghitung jumlah karakter yang diterima String buffer, kemudian hasil karakter yang diterima ditampilkan pada text2.text.

\section{a. Pengujian Implementasi}

Pengujian implementasi adalah melakukan pengujian secara keseluruhan dari perangkat keras dan perangkat lunak dengan menggunakan spesimen uji tarik sesuai. Pengujian spesimen dilakukan pada variasi spesimen benda uji dengan bahan yang berbeda, yaitu menurut pengelompokan berdasarkan bentuknya:

1. Spesimen Plat

2. Spesimen Kawat

Pengujian spesimen uji dengan variasi bahan yang berbeda dimaksudkan untuk menguji akurasi perangkat lunak visual saat merepresentasikan kinerja perangkat lunak dalam memperoleh sifat-sifat mekanis yang tergambar secara langsung dari grafik real time hubungan tegangan regangan dari masingmasing varian spesimen uji yang berbeda. Selama pengujian nilai hasil parameter dan analisa sifat mekanis spesimen didapat dengan dua perbedaan cara pengamatan yaitu:

1. Pengamatan melalui tampilan visual, nilai parameter dan grafik tegangan regangan didapat selama proses pengujian, sehingga analisa sifat mekanis dapat langsung ditentukan berdasarkan hasil data-data parameter yang telah diekspor ke dalam
MS.Access dan grafik real time tegangan (stress) dan regangan (strain) yang telah diperoleh.

2. Pengamatan secara manual, nilai parameter dan grafik diperoleh dengan cara menentukan nilai dari hasil rekaman parameter yang ditampilkan control panel LCD mesin uji tarik. Nilai parameter yang ditentukan adalah merupakan bagian dari analisa sifat mekanis yang digunakan juga sebagai parameter representasi grafik. Pengamatan secara manual merupakan cara yang biasa dilakukan user ketika melakukan pengujian pada saat praktikum.

Pengujian dilakukan di laboratorium manufaktur teknik metalurgi UNTIRTA, waktu pengujian: 11-15 Desember 2013, pengujian dilakukan pada suhu ruangan, $27^{\circ} \mathrm{C}$ (sampel plat dan sampel kawat), kecepatan tarik: $0.5 \mathrm{~ms}$.

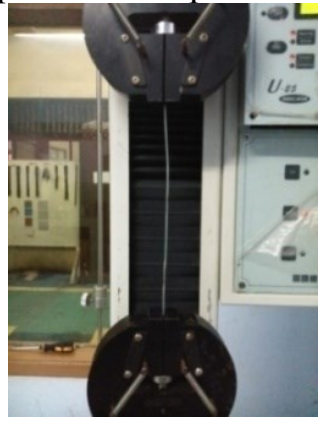

(a)

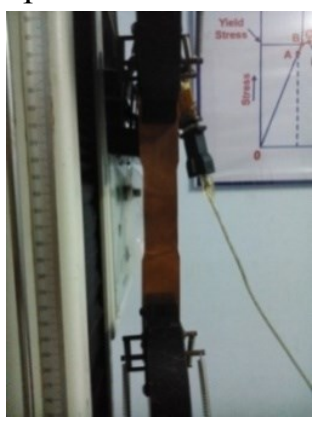

(b)
Gambar 8. (a) Posisi kawat pada grip uji tarik (b) Posisi lembaran plat pada grip uji tarik

\section{Pengujian Spesimen Plat}

Spesimen uji ini mempunyai panjang gauge length $50 \mathrm{~mm}$, dengan luas penampang adalah (panjang $(\mathrm{L}) \mathrm{x}$ lebar (t/d)) $\mathrm{mm}$.

Perolehan grafik hasil pengujian untuk masingmasing spesimen: 


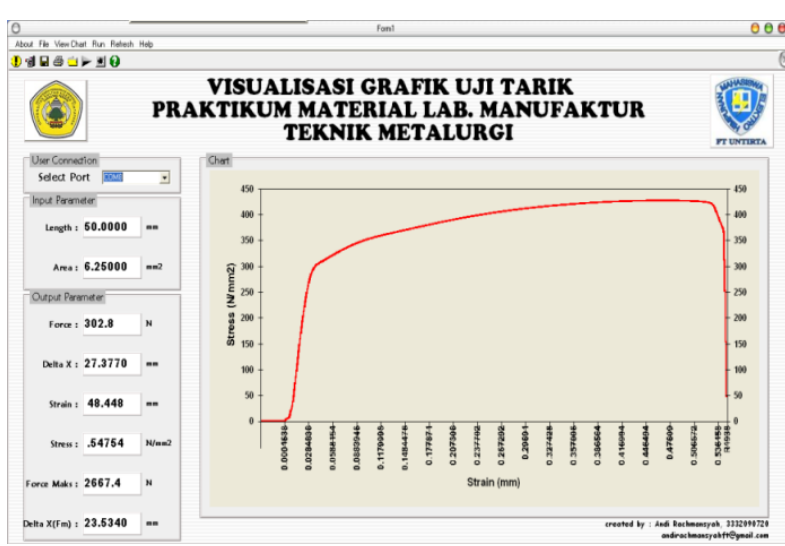

(a)

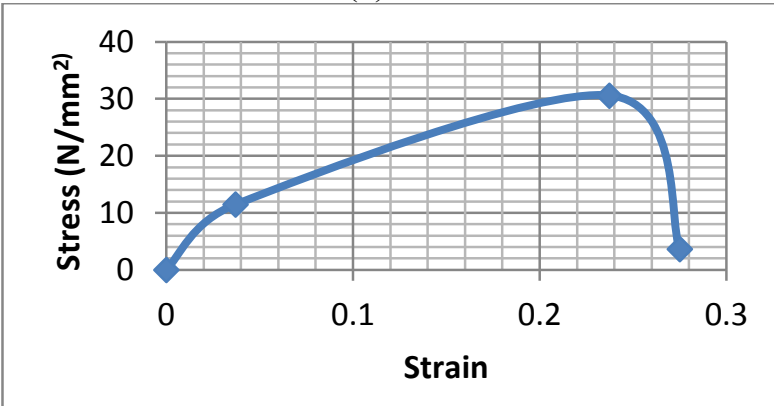

(b)

Gambar 9. (a) Grafik Hasil pengamatan visual spesimen plat baja 1 (b) Grafik hasil pengamatan manual dalam MS.Excel spesimen plat baja 1

\section{Pengujian Spesimen Kawat}

Spesimen uji ini mempunyai panjang gauge length $200 \mathrm{~mm}$, dengan luas penampang adalah $(1 / 4 \times \pi \times($ tebal/diameter $(\mathrm{t} / \mathrm{d}))) \mathrm{mm}$.

Perolehan grafik hasil pengujian untuk masingmasing spesimen:

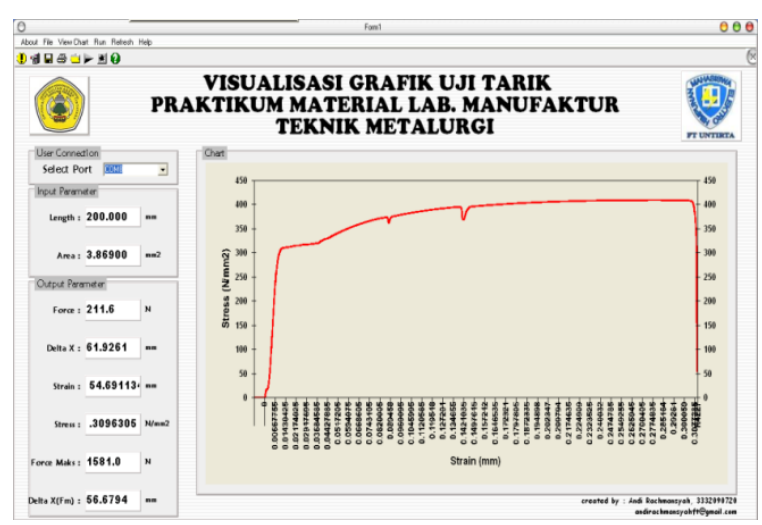

(a)

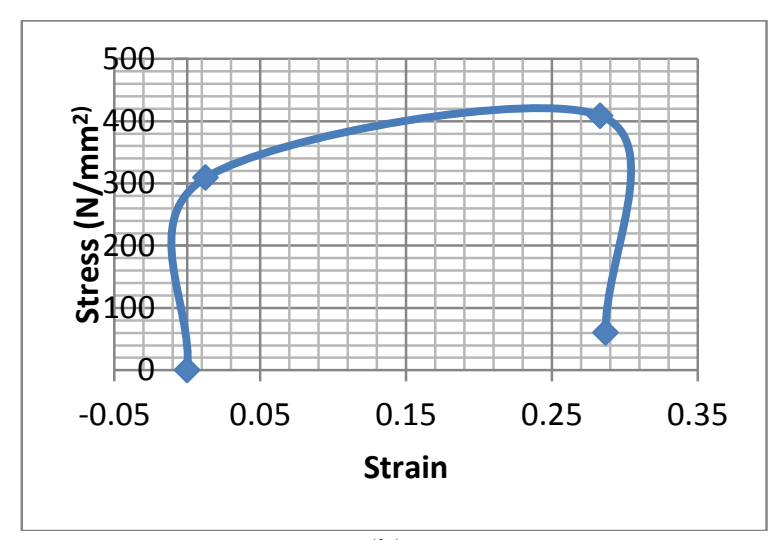

(b)

Gambar 10. (a) Grafik hasil pengamatan visual spesimen kawat baja 3 (b) Grafik hasil pengamatan manual dalam MS.Excel spesimen kawat baja 3

\section{Pembahasan Pengamatan Pengujian Spesimen}

Dari pengukuran waktu yang dibutuhkan untuk mendapatkan nilai-nilai parameter dan grafik pada masing-masing spesimen, pengamatan melalui perangkat lunak visual uji tarik lebih cepat dibanding perolehan melalui pengamatan secara manual. Karena pengamatan secara visual bersifat real time, berbeda dengan pengamatan secara manual yang membutuhkan proses lebih lanjut untuk mengetahui hasil data pengujian serta dalam menganalisa bentuk grafiknya.

Tabel 2. Perbedaan Pengamatan Visual Uji Tarik dan Pengamatan Manual

\begin{tabular}{|c|c|c|c|}
\hline $\begin{array}{c}\text { Pengam } \\
\text { atan }\end{array}$ & Hasil & $\begin{array}{c}\text { Tujuan } \\
\text { Hasil }\end{array}$ & $\begin{array}{c}\text { Penentua } \\
\text { n Nilai } \\
\text { sifat } \\
\text { mekanis }\end{array}$ \\
\hline Visual & $\begin{array}{c}\text { Grafik } \\
\text { dan nilai } \\
\text { yang di- } \\
\text { Export } \\
\text { ke } \\
\text { MS.Acc } \\
\text { ess }\end{array}$ & $\begin{array}{c}\text { Mengan } \\
\text { alisa } \\
\text { sifat } \\
\text { mekanis } \\
\text { dari } \\
\text { Grafik } \\
\text { dan data } \\
\text { Export } \\
\text { MS.Acc } \\
\text { ess }\end{array}$ & $\begin{array}{c}\text { Grafik } \\
\text { dan nilai } \\
\text { hasil } \\
\text { Export } \\
\text { Data } \\
\text { MS.Acces } \\
\text { s } \\
\text { pengujian }\end{array}$ \\
\hline
\end{tabular}




\begin{tabular}{cccc}
\hline \multirow{4}{*}{ Manual } & Nilai, & Menent & \\
& Force, & ukan & \\
& Delta X, & Nilai & Hasil \\
dari & Mekanis & Rekaman \\
& hasil & sebagai & LCD \\
& perekam & paramet & Control \\
& an LCD & er untuk & Panel \\
& Control & membua & \\
& Panel & t grafik & \\
\hline
\end{tabular}

Selama pengujian sistem secara keseluruhan terdapat perbedaan hasil nilai parameter yang didapat dan grafik tegangan vs regangan yang diperoleh antara hasil pengamatan melalui perangkat lunak visual uji tarik secara real time dengan hasil pengamatan secara manual mesin uji tarik, yaitu:

\section{Pengambilan nilai parameter}

Nilai parameter pengamatan secara manual diambil dari proses rekaman data LCD control panel mesin uji tarik, sehingga pemilihan nilai saat spesimen berada dititik kondisi-kondisi tertentu, mempengaruhi keakurasian data yang didapat. Sedangkan nilai parameter dari perangkat lunak visual uji tarik diambil langsung dari proses penangkapan nilai LCD mesin uji tarik pada perangkat lunak, sehingga ketika LCD menampilkan data informasi penting selama pengujian maka nilainilai tersebut akan langsung diproses menjadi sebuah grafik real time serta hasil data pengujian mampu direkam pada PC dan disimpan dalam bentuk basis data MS.Access.

\section{Plot grafik}

Plot grafik pengamatan secara manual hanya menggunakan tiga parameter titik uji yang didapat dari proses perekaman data LCD control panel mesin uji tarik. Tiga parameter diantaranya saat spesimen berada pada titik beban luluh (yield force) dengan pertambahan panjang saat beban luluh (Delta Xy), titik beban maksimum (maximum force) dengan pertambahan panjang saat beban maksimum (Delta Xm) dan titik beban patah (fracture force) dengan pertambahan panjang saat beban patah (Delta Xf). Sedangkan pengamatan melalui perangkat lunak visual uji tarik, plot grafik didapatkan langsung selama proses nilai riil perhitungan dalam perangkat lunak antara parameter Length, Area, Force dan Delta X (sesuai dengan persamaan 2.1 dan persamaan
2.2) selama proses pengujian.

\section{KESIMPULAN}

1. Mesin uji tarik Gotech GT-7010-D2E mampu terkoneksi ke PC dengan baik, yaitu dengan menggunakan perangkat keras tambahan berupa kit capture LCD teks $2 \times 16$.

2. Rancangan tampilan visualisasi sebagai fasilitas pendukung instrumen mesin uji tarik Gotech GT-7010-D2E, mampu menampilkan dengan baik setiap data parameter pendukung seperti nilai Length, Area, Force, Delta X, Stress, Strain, Force Maximum, dan Delta X(Force Max) serta representasi grafik tegangan dan regangan yang diperoleh secara real time selama pengujian.

3. Setelah dilakukan pegujian spesimen secara keseluruhan, pengamatan melalui perangkat lunak visual cenderung lebih akurat terhadap perbedaan pengamatan manual yang biasa dilakukan. Sedangkan dari segi efisiensi penggunaan waktu untuk memperoleh data pengujian, pengamatan secara visual lebih efektif dibanding dengan pengamatan secara manual.

4. Perangkat lunak visual mampu melakukan proses perekaman dengan baik selama pengujian, dalam bentuk basis data Microsoft Access, hasil pengujian dapat langsung dicetak ataupun disimpan untuk analisa lebih lanjut.

\section{DAFTAR PUSTAKA}

[1] Repaldo, Dimas, Contoh Laporan Material Teknik Uji Tarik, Jakarta, (2013).

[2] Rafe'I, Ahmadi, Laporan Material Teknik, Jurusan Teknik Metalurgi UNTIRTA Cilegon, (2011).

[3] Walid, Mohamad, Perencanaan dan Pembuatan Alat Bantu Uji Tarik Untuk Menunjang praktikum Uji Tarik pada LAB. Logam UMM Berbasis PC, Skripsi Jurusan Teknik Elektro Universitas Muhammadiyah Malang, (2003).

[4] Nazi, Khoirun, Perancangan dan Pembuatan Interface Alat Uji Tarik Serat 
Berbasis PC dan Mikrokontroler, Tesis Jurusan Teknik Fisika UNBRAW, (2011).

[5] Mualif, Slamet, Pembuatan Alat Uji Tarik Material. Skripsi Jurusan Fisika Instrumentasi Universitas Indonesia, (2012).

\section{Biodata Penulis}

Anggoro Suryo Pramudyo; S1 Teknik Informatika, S2 Ilmu Komputer; Bidang keahlian kecerdasan buatan dan rekayasa perangkat lunak.

Andi Rachmansyah; S1 Teknik Elektro; Bidang keahlian desain perangkat keras berbasis mikrokontroler.

Suhendar; S1 Pendidikan Elektro, S2 Teknik Elektro; Bidang keahlian sistem tenaga listrik dan elektronika industri. 